\title{
A new species of Andracantha Schmidt (Acanthocephala, Polymorphidae) parasite of Neotropical cormorants, Phalacrocorax brasilianus (Gmelin) (Aves, Phalacrocoracidae) from southern Brazil ${ }^{1}$
}

\author{
Cassandra M. Monteiro ${ }^{3}$; José F. R. Amato ${ }^{2} \&$ Suzana B. Amato ${ }^{2}$ \\ ${ }^{1}$ Contribution number 478 of the Departamento de Zoologia, Universidade Federal do Rio Grande do Sul. \\ ${ }^{2}$ Departamento de Zoologia, Instituto de Biociências, Universidade Federal do Rio Grande do Sul. Caixa Postal 15014, \\ 91501-970 Porto Alegre, Rio Grande do Sul, Brasil.E-mail: jfamato@terra.com.br and sbamato@ufrgs.br \\ 3 Bolsista CAPES. E-mail: cassandra.monteiro@terra.com.br
}

\begin{abstract}
A new species of the genus Andracantha Schmidt, 1975, parasite of Neotropical cormorants, Phalacrocorax brasilianus (Gmelin, 1789), is described and compared to the other six species currently placed in the genus. The new species differs from the previously known species of Andracantha by having two inflations in the anterior region of the trunk and by having the testes in tandem in the central region of the body. These differences were also responsible for the diagnosis emendation of the genus now proposed. The orange pigmentation of the acanthocephalans recently collected from the intestine is documented for the first time in a species of this genus. This is the first record of adult specimens of any species of Andracantha in South America.

KEY WORDS. Body pigment; genus emendation; helminths; Rio Grande do Sul; taxonomy.
\end{abstract}

\begin{abstract}
RESUMO. Nova espécie de Andracantha Schmidt (Acanthocephala, Polymorphidae) parasita de biguás, Phalacrocorax brasilianus (Gmelin) (Aves, Phalacrocoracidae) da região Sul do Brasil. Uma nova espécie do gênero Andracantha Schmidt, 1975, parasita de biguás (cormorões neotropicais), Phalacrocorax brasilianus (Gmelin, 1789), é descrita e comparada com as outras seis espécies atualmente incluídas no gênero. A nova espécie difere das demais espécies previamente conhecidas de Andracantha por ter duas inflações na região anterior do corpo e por ter testículos em tandem na região central do corpo. Estas diferenças também são responsáveis pela emenda na diagnose do gênero agora proposta. Pela primeira vez é documentada a pigmentação alaranjada de acantocéfalos recém coletados do intestino, em qualquer espécie do gênero. Este é o primeiro registro de espécimes adultos do gênero Andracantha na América do Sul.
\end{abstract}

PALAVRAS-CHAVE. Biguás; emenda do gênero; helmintos; pigmentação do corpo; taxonomia.

The genus Andracantha was proposed by ScHмiDT (1975) to group species transferred from Corynosoma Lühe, 1904. Both genera have as diagnostic characters the presence of trunk and genital spines. In the species of Corynosoma the trunk spines are arranged in a single field, while in the species of Andracantha they are arranged in two separate fields (with a bare zone between them, or sparsely spined, as found in Andracantha baylisi (Zdzitowiecki, 1986) Zdzitowiecki, 1989) which can be connected in the dorsal region.

When Schmidt proposed Andracantha, he included only three species in the genus: Andracantha gravida (Alegret, 1941) Schmidt, 1975 - the type species, Andracantha phalacrocoracis (Yamaguti, 1939) Schmidt, 1975, and Andracantha mergi (Lundström, 1941) Schmidt, 1975. ZDZITOWIECKI (1986) redescribed Corynosoma tunitae Weiss, 1914 and described Corynosoma baylisi, which later (ZDZITOWIECKI 1989) were transferred, together with Corynosoma clavata Goss, 1940, to Andracantha, making three new combinations: Andracantha tunitae (Weiss, 1914) Zdzitowiecki, 1989, A. baylisi, and Andracantha clavata (Goss, 1940) Zdzitowiecki, 1989. ZDZITOWIECKI (1989) emended the genus diagnosis. Since then, no other species have been described or transferred to Andracantha. Life cycles of the species in this genus are unknown (Nickol et al. 2002), although the presence of fishes as paratenic hosts had already been recorded for $A$. baylisi (ZDZITOWIECKI 1986).

Five of the six species of Andracantha have piscivorous birds (shags and cormorants) of the genus Phalacrocorax Brisson, 1760, as type hosts. Andracantha gravida has the Double-crested Cormorant, Phalacrocorax auritus floridanus (Audubon, 1835), A. phalacrocoracis has the Pelagic Cormorant, Phalacrocorax 
pelagicus Pallas, 1811, A. tunitae has the Great Cormorant, Phalacrocorax carbo (Linnaeus, 1758), A. baylisi has the King Cormorant, Phalacrocorax albiventer (Lesson, 1831) as type hosts. Andracantha clavata, when described by Goss (1940), had been listed as occurring in the Large-pied Shag, Phalacrocorax varius (Gmelin, 1789), as well as in the Little Black Cormorant, [Phalacrocorax sulcirostris (Brandt, 1837) = Phalacrocorax ater of Goss (1940)], and in the Small-pied Shag, Phalacrocorax melanoleucus (Vieillot, 1817), but without indication of which species was the type host. Andracantha mergi, is found in several species of piscivorous birds, being the Red-breasted Merganser, Mergus serrator Linnaeus, 1758 its type host. NicKol \& Kocan (1982) and Richardson \& Cole (1997) have recorded A. mergi in the American Bald Eagle, Haliaeetus leucocephalus (Linnaeus, 1766), the only record of non Phalacrocoracidae host for any species of Andracantha.

The Neotropical Cormorant, Phalacrocorax brasilianus (Gmelin, 1789) occurs from Tierra del Fuego, Patagonia, Argentina to coastal Texas, USA, the northernmost extreme of its known geographical distribution (DEL Hoyo et al. 1992, apud Fedynich et al. 1997). This species has been reported to be the host of A. gravida in Texas (Fedynich et al. 1997), as well as the host of Corynosoma arctocephali Zdzitowiecki, 1984, in Llanquihue, southern Chile (Torres et al. 1993).

The objective of the present study is to describe a new species of the genus Andracantha, emend the genus, document the body pigmentation of these helminths before fixation, and record for the first time the presence of adult acanthocephalans of this genus in South America.

\section{MATERIAL AND METHODS}

Forty-seven Neotropical cormorants, P. brasilianus were collected from Lago Guaíba, Municipality of Guaíba, Rio Grande do Sul, from 1999 to 2003, in accordance with established guidelines and protocols from the IBAMA (Instituto Brasileiro do Meio Ambiente e dos Recursos Renováveis) and scientific collection permits numbers 232/1999 and 064/2002, issued in the name of the second author. Cormorants were frozen at $-10^{\circ} \mathrm{C}$, as soon as possible after the catch. Necropsies were performed in the Laboratório de Helmintologia, Departamento de Zoologia, Universidade Federal do Rio Grande do Sul, Brazil. Necropsy procedures, collection, and processing of parasites followed Aмato et al. (1991).

Some specimens were photographed before fixation to record their orange pigmentation and then stored in ethanol $70^{\circ} \mathrm{GL}$. Other specimens were fixed in AFA $\left(70^{\circ} \mathrm{GL}\right.$ ethanol -93 parts, formalin $37 \%$ - five parts, glacial acetic acid - two parts), under slight cover slip pressure, stained in Delafield's hematoxylin (Humason 1972), cleared in beech wood creosote, and mounted in Canada balsam. Drawings were made with a drawing tube, while photomicrographs were taken with a Zeiss Axiolab microscope and/or with a digital camera. Both were scanned and prepared using Adobe's Photoshop CS ${ }^{\circledR}$. Measure- ments are in micrometers $(\mu \mathrm{m})$ unless otherwise indicated, ranges are followed (between parentheses) by the mean, the number of specimens measured for a given character and the standard deviation values. Ecological terms such as prevalence, mean intensity of infection, mean abundance of infection, and range follow Bush et al. (1997). The holotype, the allotype, and one paratype were deposited in the Coleção Helmintológica do Instituto Oswaldo Cruz (CHIOC), Rio de Janeiro, Brazil.

\section{RESULTS}

\section{Andracantha tandemtesticulata sp. nov.}

\section{Figs 1-9}

Description. Based on nine whole mounted specimens (four males and five females). Polymorphidae. Females slightly larger than males (Figs 1, 2, 5, 6, and 9). Tegument with orange pigmentation not uniform, darker in anterior trunk of females (Figs 1 and 2). Proboscis swollen in middle third or posterior half (Fig. 8). Neck as long as proboscis (Figs 5, 6, 8, and 9). Body, in uncompressed specimens, with two inflations, one anterior, at level of posterior field of spines, followed by a constriction immediately after it, and a wider inflation, at mid trunk. Anterior portion of trunk with spines distributed in two distinct fields (Figs 5, 6, and 9), with similar dorsal and ventral width. Anterior field of trunk spines with 5 or 6 transversal rows of spines; posterior field of trunk spines with 8-10 transversal rows of spines; bare zone between fields of trunk spines with approximately same width. Lemnisci broad, with rounded tips, longer than proboscis receptacle, at least in males. Genital pore terminal in both sexes; genital spines not observed.

Males (Figs 1 and 6). Body 4.0-7.4 $\mathrm{mm}(5.4 \mathrm{~mm}, \mathrm{n}=4$, $1.7 \mathrm{~mm})$ long, 0.9-1.7 mm $(1.3 \mathrm{~mm}, \mathrm{n}=4,0.4 \mathrm{~mm})$ in greatest width. Proboscis 690-740 (723, $\mathrm{n}=3,29)$ long, 250-290 (267, $\mathrm{n}$ $=3,21$ ) wide; hooks in 18 longitudinal rows of 14 to 16 each (Fig. 7); first eight hooks with similar shape and size, without one hook stouter than others; with well developed roots, without manubrium; 6 to 8 spines with poorly developed roots, small manubrium; hooks 37-55 $(44, \mathrm{n}=48,4)$; spines $32-45$ $(40, \mathrm{n}=42,2)$. Neck 600-829 (740, $\mathrm{n}=5$, 91) long, 474-731 $(582, \mathrm{n}=5,115)$ wide at base. Trunk spines in anterior field 13$18(16, \mathrm{n}=10,2)$ long, in posterior field 23-31 $(28, \mathrm{n}=10,3)$ long; genital spines not observed. Proboscis receptacle 1.2-1.4 $\mathrm{mm}(1.3 \mathrm{~mm}, \mathrm{n}=4,0.1 \mathrm{~mm})$ long, 316-336 $(323, \mathrm{n}=4,11)$ wide. Testes in tandem, ovate to round; anterior testis 210-620 (397, $\mathrm{n}=4$, 207) long, $160-530(317, \mathrm{n}=4,191)$ wide; posterior testis 220-670 (432, $\mathrm{n}=4,187)$ long, 170-550 (320, $\mathrm{n}=4$, 162) wide; six elongated cement glands, grouped in pairs, Saefftigen's pouch conspicuous when filled with fluid, 260-940 (600, $\mathrm{n}=2$, 481) long, 170 wide $(\mathrm{n}=1)$; copulatory bursa small, introverted in the majority of the specimens.

Females (Figs 2 and 9). Body 6.5-10.5 mm ( $8.8 \mathrm{~mm}, \mathrm{n}=5$, $1.6 \mathrm{~mm})$ long, $1.4-2.1 \mathrm{~mm}(1.8 \mathrm{~mm}, \mathrm{n}=5,0.3 \mathrm{~mm})$ in greatest width. Proboscis 711-849 $(772, \mathrm{n}=5,54)$ long, 210-290 (256, 

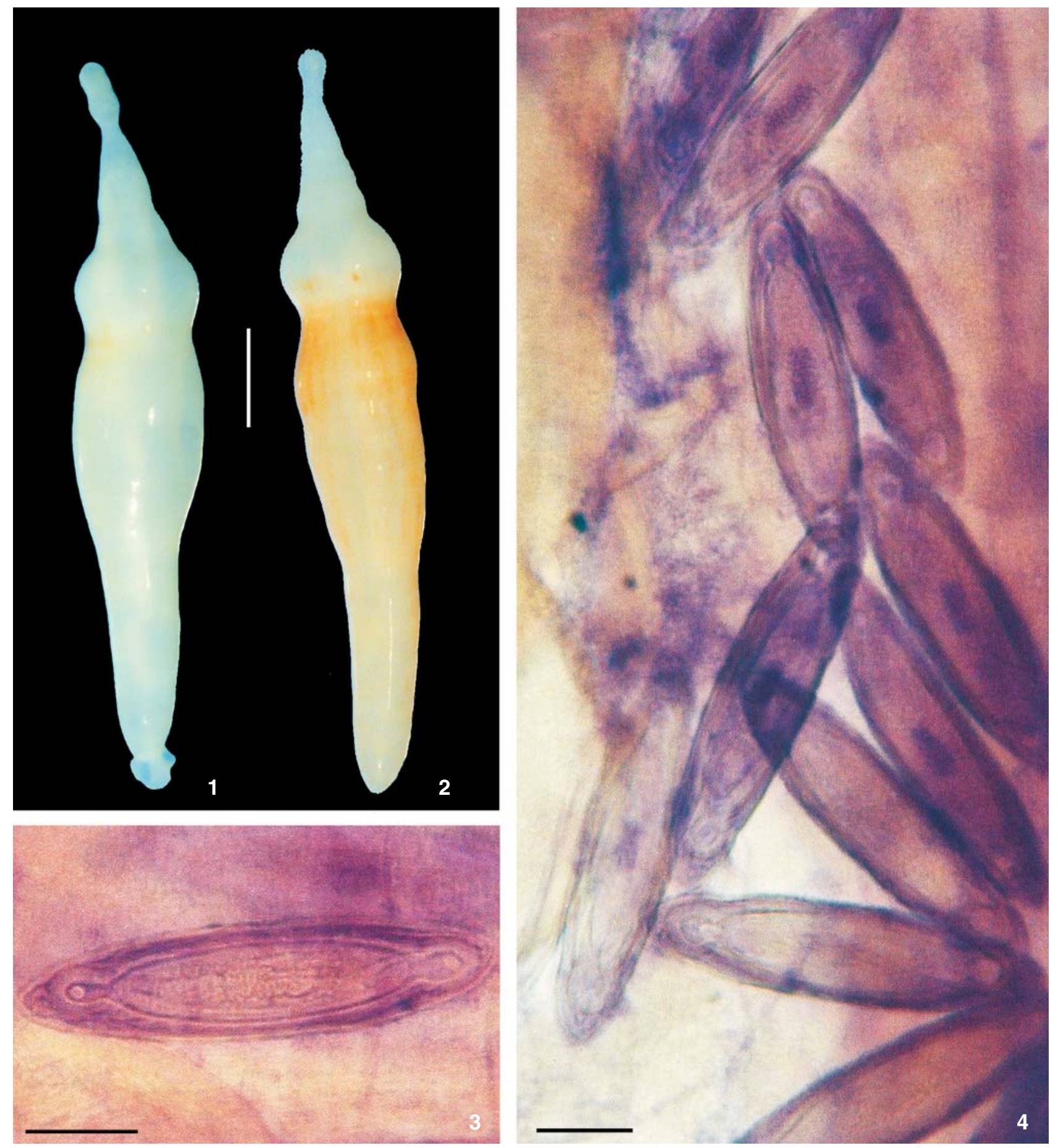

Figures 1-4. Andracantha tandemtesticulata sp. nov., parasite of Neotropical cormorants, Phalacrocorax brasilianus: (1-2) body pigment, specimens without compression (1) male, paratype without compression; (2) female, paratype without compression, bar = $1 \mathrm{~mm}$; (3) egg showing polar inflations, bar = $25 \mu \mathrm{m}$; (4) eggs showing polar inflations and stained embryos, fotographed throught the body wall, bar $=25 \mu \mathrm{m}$. 


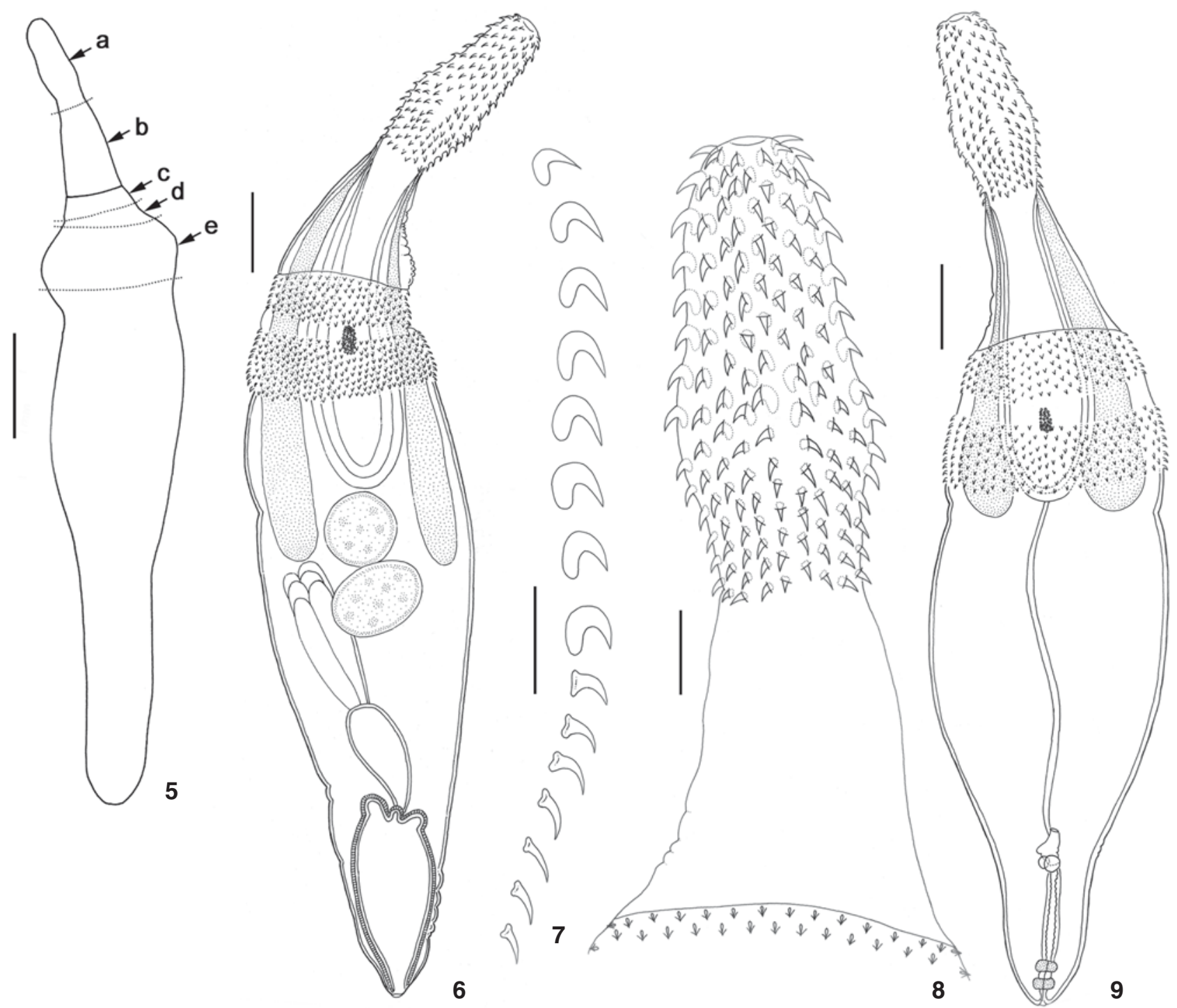

Figures 5-9. Andracantha tandemtesticulata sp. nov., parasite of Neotropical cormorants, Phalacrocorax brasilianus. (5) Body contour, showing: (a) proboscis, (b) neck, (c) anterior field of trunk spines, (d) bare zone, (e) posterior field of trunk spines and anterior inflation zone, bar = $1 \mathrm{~mm}$; (6) male, holotype, bar $=250 \mu \mathrm{m}$; (7) complete longitudinal row of eight hooks and seven spines, bar $=100 \mu \mathrm{m}$. (8) presoma (proboscis + neck), bar $=100 \mu \mathrm{m}$; (9) female, allotype, bar $=250 \mu \mathrm{m}$.

$\mathrm{n}=5,30$ ) wide; hooks in 16 to 19 longitudinal rows of 14 to 17 hooks each; first 8 hooks with roots well developed, without manubrium; 6 to 9 spines with poorly developed roots and small manubrium, as in males; hooks 35-60 $(48, \mathrm{n}=48,5)$; spines 35 $48(41, \mathrm{n}=39,3)$. Neck 0.7-1.1 mm (0.9 mm, $\mathrm{n}=5,0.2 \mathrm{~mm})$. Proboscis receptacle 1.0-1.7 $\mathrm{mm}(1.4 \mathrm{~mm}, \mathrm{n}=5,0.4 \mathrm{~mm})$ long, 258-355 (306, $\mathrm{n}=5,70)$ wide. Uterine bell 782-877 (830, $\mathrm{n}=2$, 67) from posterior extremity of body; vagina with two muscular sphincters; eggs (Figs 3 and 4) with three envelopes; middle envelope with large polar swellings, 80-107 $(93, \mathrm{n}=16,8)$ long,
22-27 $(25, \mathrm{n}=16,2)$ wide.

Type host. Neotropical Cormorant ('biguá'), Phalacrocorax brasilianus (Gmelin, 1789).

Site of infection. Small and large intestines.

Locality. Lago Guaíba, Municipality of Guaíba, RS, Brazil $\left(30^{\circ} 00^{\prime} \mathrm{S}, 51^{\circ} 15^{\prime} \mathrm{W}\right)$.

Prevalence. $21.27 \%$.

Mean intensity of infection. 6.80 helminths/host. Mean abundance of infection. 1.45 helminths/host. Range. 1-25 helminths/host. 
Deposited specimens. CHIOC $\mathrm{N}^{\circ}$ 36630a (holotype male), CHIOC No 36630b (allotype female), CHIOC $\mathrm{N}^{\circ} 36630 \mathrm{c}$ (paratype).

Etymology. (L. tandemtesticulata - composite adjective (adverb tandem + adjective testiculata), of $1^{\text {st }}$ class (triform), agreeing with the generic name, Andracantha. The specific epithet tandemtesticulata was given after the new species is the only one in the genus to have the testes one behind the other, i.e. in tandem, instead in the bilateral position.

Remarks. Andracantha, shares characters with Corynosoma and Southwellina Witenberg, 1932, which have species parasites of piscivorous animals. Characters shared by Andracantha and Southwellina are: the proboscis shape, the double-walled proboscis pouch inserted at base of proboscis, the conspicuous neck, and the presence of trunk spines disposed in two separate fields with a bare zone between them. The species of Andracantha can be distinguished from the species of Southwellina by the presence of genital spines (although A. mergi at the time of the original description and $A$. tandemtesticulata sp. nov., so far have not been found to have genital spines) and for having 8 or 6 cement glands, respectively, instead of 4. Aznar et al. (2002) have suggested that the absence of genital spines should be avoided as the sole criterion to exclude specimens from Corynosoma or Andracantha. According to RichaRdson \& COLE (1997), species in these genera could also be distinguished by the spineless zone between the fields of trunk spines with similar width dorsally and ventrally, the hooks never exceeding $65 \mu \mathrm{m}$ in length, and the eggs with conspicuous swellings in the fertilization membrane. Now, with the description of $A$. tandemtesticulata sp. nov., the width of the spineless zone is more uniform than what had been previously observed, the testes are in tandem, and the eggs have large and conspicuous swellings in the fertilization membrane, as in the species of Southwellina.

The proboscis in males of $A$. tandemtesticulata sp. nov. has 18 longitudinal rows of 14 to 16 hooks each, more than in $A$. gravida (16 and 11-12), A. mergi (15-17 and 10), A. baylisi (16 and 10), A. tunitae (10-12 and 14-16), and A. clavata (14 and 10$11)$, but within the range in the number of longitudinal rows that is found in A. phalacrocoracis (16-19 and 13 or 14). The proboscis in females of $A$. tandemtesticulata sp. nov. has 16 to 19 longitudinal rows of 14 to 17 hooks each in row, within the range found in A. gravida (16-17 and 11-12), A. mergi (16 and 9. 10), A. baylisi (16 and 10), but more than the number found in A. tunitae (10-12 and 16-19), A. clavata (14 and 10-11), and A. phalacrocoracis (17-19 and 10-14). As in most of the other species in the genus there are differences in the number of hooks/ spines between males and females.

Our specimens differ from $A$. phalacrocoracis by having 6 cement glands instead of 8 ; and from all other species of the genus by the position of testes which are arranged in tandem, instead of being bilateral. The testes in A. tandemtesticulata sp. nov. and in $A$. tunitae are in the second third of the trunk, while in the other species they are in the first third.

The eggs of $A$. tandemtesticulata sp. nov., are much slen- der when compared with the eggs in all other species in the genus Andracantha, in addition to have well developed polar inflations in the middle envelope. In A. clavata, the presence of polar inflations has not been described. The new species also has the uterine bell much closer to the posterior extremity than all the other species. This might be explained by the fact that, at least in the type specimens, the posterior, more slender portion of the hind trunk did not develop fully, as can be seen in the specimens of figures 5,6 , and 9, despite the fact that those specimens are adults. The first hook of each longitudinal row of hooks/ spines lacks a manubrium. In the new species it has a shape similar to the other hooks on the same longitudinal row, without a larger and stouter hook before the spines in each row, which distinguishes the new species. The presence of genital spines is a character shared with the species of the genus Corynosoma. In Andracantha, the genital spines may be present in males and/or females and may vary in position and/or number. Genital spines were not observed in A. tunitae (ZDzITOwIECKI 1986) and neither in A. tandemtesticulata sp. nov. According to SснміDт (1975) a few spines were observed on several juvenile and adult females of $A$. mergi in the original description, although no spines have been found in the specimens collected and described by him. After the original description of a few spines on several females collected in Sweden, only BELOPOLSKAYA (1958 apud NicKol \& KoCAN 1982) illustrated the spines on a single female of A. mergi collected in Siberia. NicKOL \& Kocan (1982) documented photographically a single spine on a female of $A$. mergi found in a bald eagle from North America.

The diagnosis of Andracantha appears insufficient to include all the species known to date (including the new species now being described) requiring a new emendation, additionally to that given by ZDzIтошіEсKI (1989) when describing A. baylisi, which had characters not included in the diagnosis of the genus.

\section{Andracantha Schmidt, 1975, emended}

Diagnoses. Proboscis cylindrical with or without a swollen area, armed with numerous rows of hooks. Neck conspicuous. Anterior trunk with one or two swollen areas and two fields of spines separated by a bare zone or by a zone of smaller, dispersed spines. Genital spines present on at least one sex, sometimes missing on individuals, sometimes shifted anteriorly to the genital pore on the ventral surface. Proboscis receptacle double-walled, inserted at the base of proboscis. Testes in anterior or medium third of body; bilateral or in tandem. Six or eight, swollen and tubular, cement glands, usually arranged in bilateral pairs. Eggs with or without polar swellings of the middle membrane. Parasites of fish-eating birds and American bald eagles.

Type species: A. gravida (Alegret, 1941) Schmidt, 1975.

\section{DISCUSSION}

Threlfall (1982) registered the presence of a complex of species in double-crested cormorants, P. auritus, with the preva-

Revista Brasileira de Zoologia 23 (3): 807-812, setembro, 2006 
lence and mean intensities in the East and West coasts of Florida of $34 \%$ and 5 , and $74 \%$ and 24, respectively. Munro et al. (1995) registered $A$. tunitae in shags, $P$. aristotelis, with the prevalence of $69 \%$ and mean intensity of infection of 5 specimens per host. FEDYNICH et al. (1997) registered A. gravida in P. brasilianus and $P$. auritus, in Texas, USA, with prevalences of $67 \%$ and $58 \%$, and mean intensity of infection of 2 and 2.7 specimens per host, respectively. Comparing our results with those of the previous authors, the present work shows the smaller prevalence and a similar mean intensity of infection than those reported by these authors. Body pigmentation in acanthocephalans has been reported by several authors, among them BARRETT \& BUtTERWORTH (1973), who extracted lutein, B-carotene, and esterefied astaxanthin from six species in archiacanthocephalans, palaeacanthocephalans, and eoacanthocephalans, but is has not been reported for species of Andracantha.

\section{ACKNOWLEDGEMENTS}

To Ibama, for the permission to capture the hosts; to CAPES for the scholarship given to the senior author. To Abner Chiquieri, Departamento de Línguas, Universidade Federal Rural do Rio de Janeiro, Seropédica, for his advice on the formation of the specific name of the new species. To Glayson A. Bencke, Fundação Zoobotânica do Estado do Rio Grande do Sul, Porto Alegre, for providing valuable information on birds' nomenclature and authorships. To Luís C. Muniz, Instituto Oswaldo Cruz, Rio de Janeiro; Laura R. Utz, Departamento de Zoologia, Universidade Federal do Rio Grande do Sul; Samantha A. Seixas and Luiz Carlos Campos Daudt.

\section{REFERENCES}

Amato, J.F.R.; W. Böeger \& S.B. Amato. 1991. Protocolos para laboratório: coleta e processamento de parasitos de pescado. Seropédica, Gráfica da Universidade Federal Rural do Rio de Janeiro, 81p.

Aznar, F.J.; B. Béron-Vera; E.A. Crespo \& J.F. Raja. 2002. Presence of genital spines in a male Corynosoma cetaceum Johnston and Best, 1942 (Acanthocephala). Journal of Parasitology, Lawrence, 88 (2): 403-404.

Barrett, J. \& P.E. Butterworth. 1973. The carotenoid pigments of six species of adult Acanthocephala. Experientia, Basel, 29 (6): 651-653.

Bush, A.O.; K.D. Lafferty; J.M. Lotz \& A.W. Shostak. 1997. Parasitology meets Ecology on its own terms: Margolis et al. revisited. Journal of Parasitology, Lawrence, 83 (4): 575-583.

Received in 18.XI.2005; accepted in 25.VIII.2006.
Fedynich, A.M.; D.B. Pence \& J.F. Bergan. 1997. Helminth community structure and pattern in sympatric populations of double-crested and Neotropic cormorants. Journal of Helminthological Society of Washington, Lawrence, 64 (2): 176-182.

Goss, O.M. 1940. Platyhelminth and acanthocephalan parasites of local shags. Journal of the Royal Society of Western Australia, Perth, 26: 1-14.

Humason, G.L. 1972. Animal Tissue Techniques. San Francisco, W.H. Freeman, 641p.

MunRo, J.F.; D.W.T. CROMPTon \& R.C. StodDarT. 1995. Andracantha tunitae (Acanthocephala) in the shag (Phalacrocorax aristotelis) from Shetland, Scotland. Journal of Parasitology, Lawrence, 81 (3): 496-498.

Nickol, B.B. \& A.A. Kocan. 1982. Andracantha mergi: (Acanthocephala, Polymorphidae) from American Bald Eagles, Haliaeetus leucocephalus. Journal of Parasitology, Lawrence, 68 (1): 168-169.

Nickol, B.B.; R.W. HeARd \& N.F. SMitH. 2002. Acanthocephalans from crabs in the southeastern U.S., with the first intermediate hosts known for Arhythmorhynchus frassoni and Hexaglandula corynosoma. Journal of Parasitology, Lawrence, 88 (1): 79-83.

Richardson, D.J. \& R.A. Cole. 1997. Acanthocephala of the bald eagle (Haliaeetus leucocephalus) in North America. Journal of Parasitology, Lawrence, 83 (3): 540-541.

Schмid, G.D. 1975. Andracantha, a new genus of Acanthocephala (Polymorphidae) from fish-eating birds, with descriptions of three species. Journal of Parasitology, Lawrence, 61 (4): 615-620.

Threlfall, W. 1982. Endoparasites of the double-crested cormorant (Phalacrocorax auritus) in Florida. Proceedings of the Helminthological Society of Washington, Lawrence, 49 (1): 103-108.

Torres, P.R.; R. Schlatter; A. Montefusco; W. Gesche; E. Ruiz \& A. Contreras. 1993. Helminth parasites of piscivorous birds from lakes in the south of Chile. Memórias do Instituto Oswaldo Cruz, Rio de Janeiro, 88 (2): 341-343.

ZDZITOWIECKI, K. 1986. Redescription of Corynosoma tunitae (Weiss, 1914) and description of C. baylisi sp. n. (Acanthocephala, Polymorphidae), parasites of piscivorous birds. Acta Parasitologica Polonica, Warszawa, 31 (14): 117-123.

ZDZITOWIECKI, K. 1989. New data on the morphology and distribution of two acanthocephalans, Andracantha baylisi (Zdzitowiecki, 1986) comb. nov. and Corynosoma australe Johnston, 1937. Acta Parasitologica Polonica, Warszawa, 34 (2): 167 172.

Revista Brasileira de Zoologia 23 (3): 807-812, setembro, 2006 